\title{
Models of $\beta$-amyloid induced Tau-pathology: the long and "folded" road to understand the mechanism
}

\author{
$\|_{\text {lie-Cosmin Stancu }}{ }^{1 \dagger}$, Bruno Vasconcelos ${ }^{1 \dagger}$, Dick Terwel ${ }^{2}$ and Ilse Dewachter ${ }^{1 *}$
}

\begin{abstract}
The amyloid cascade hypothesis has been the prevailing hypothesis in Alzheimer's Disease research, although the final and most wanted proof i.e. fully successful anti-amyloid clinical trials in patients, is still lacking. This may require a better in depth understanding of the cascade. Particularly, the exact toxic forms of A $\beta$ and Tau, the molecular link between them and their respective contributions to the disease process need to be identified in detail. Although the lack of final proof has raised substantial criticism on the hypothesis per se, accumulating experimental evidence in in vitro models, in vivo models and from biomarkers analysis in patients supports the amyloid cascade and particularly $A \beta$-induced Tau-pathology, which is the focus of this review. We here discuss available models that recapitulate $A \beta$-induced Tau-pathology and review some potential underlying mechanisms. The availability and diversity of these models that mimic the amyloid cascade partially or more complete, provide tools to study remaining questions, which are crucial for development of therapeutic strategies for Alzheimer's Disease.
\end{abstract}

Keywords: Amyloid, Tau, Alzheimer's disease, Animal models, Amyloid cascade hypothesis, Synaptic dysfunction, Inflammation, Prion

\section{The amyloid cascade hypothesis and anti-A $\beta$ directed therapies}

Brains of Alzheimer's Disease (AD) patients are characterized by the presence of amyloid plaques and neurofibrillary tangles (NFTs) as diagnostic hallmarks, in addition to reactive microgliosis and astrogliosis, synaptic and neuronal loss, and a marked brain atrophy [1-5]. Identification of mutations in amyloid precursor protein (APP) and presenilin (PS1/2) that are autosomal dominantly linked to early onset familial $\mathrm{AD}$ [6,7], represented major milestones in $\mathrm{AD}$ research. The histopathological similarity between sporadic and early familial cases was taken as evidence for a common etiology of the disease. Because in vitro and in vivo data indicated that Early Onset Familial Alzheimer's Disease (EOFAD) mutations give rise to the generation of more $\beta$-amyloid $(A \beta)$ peptides or more amyloidogenic

\footnotetext{
* Correspondence: Ilse.Dewachter@uclouvain.be

${ }^{\dagger}$ Equal contributors

'Catholic University of Louvain, Institute of Neuroscience, Alzheimer Dementia, Av. E. Mounier 53, Av. Hippocrate 54, B-1200 Brussels, Belgium Full list of author information is available at the end of the article
}

species, their accumulation was postulated to be the cause of the disease process. Hence, it was postulated that accumulation of more amyloidogenic peptides results in a cascade of events leading to increased inflammation, Tau pathology, synaptic and neuronal loss, ultimately responsible for the clinical symptoms of $\mathrm{AD}$ [1]. In contrast, exonic and intronic mutations in MAPT, the gene encoding Tau, are associated with neurodegenerative diseases, but not with $\mathrm{AD}[8,9]$, and hence do not result in amyloid pathology.

Accumulating evidence for a causal role of amyloid peptides in $\mathrm{AD}$ etiology resulted in a quest for antiamyloid directed targets, which was particularly pursued preclinically in APP and APP/PS1 overexpressing transgenic mice. These models develop robust amyloid pathology, gliosis and synaptic and behavioral deficits including cognitive deficits -, parameters that were used as read-outs for successful preclinical trials. Identification of alpha-secretase (ADAM10 [10], TACE), beta-secretase (BACE1 [11]) and gamma-secretase (as a complex containing aph1, pen2, nicastrin, PS1 [12,13]) and the analysis of their potential as therapeutic targets 
in preclinical models [14], prompted straightforward small molecule-based approaches. In addition, other non-secretase directed approaches were developed including the more unexpected, atypical approach of active and passive immunization against $A \beta[15,16]$.

\section{The amyloid cascade hypothesis: criticism raised by lack of successful clinical trials fueled interest in Tau-directed therapies}

However, anti-A $\beta$ directed clinical trials in $\mathrm{AD}$ patients have been incompletely satisfying or disappointing either by lack of amyloid lowering effects or by disappointing outcomes [17] including following immunization, i.e. marked removal of amyloid plaques without halting/ slowing disease progression. Hence these outcomes indicated (i) technical issues, (ii) the preventive ('early') rather than curative ('late') potential of anti-amyloid therapies, and (iii) revealed the necessity of multi-target therapies combining anti-amyloid with therapies aiming at Tau - as a "late target" - able to halt the execution of the pathogenetic cascade. Most importantly clinical trials aiming at amyloid plaques highlighted the lack of in depth understanding of (i) the molecular identity of the toxic $A \beta$ (and Tau) forms, (ii) the mechanisms linking both diagnostic pathologies (amyloid and Tau) - and eventually associated pathological features including inflammation, synaptic loss, brain atrophy and (iii) the respective contributions of both pathological proteins to the etiology of $\mathrm{AD}$. Indeed, arising insights encompassed that either not the or not all toxic forms of $A \beta$ were removed, or that administration of the vaccine occurred too late in the disease process, after initiation of a pathogenetic cascade by $A \beta$, which can be self-propagating and Tau-driven. Alternatively, independent pathogenetic roles of $A \beta$ and Tau were invoked [18]. The interest in Tau as a "late target" for combined therapy - as crucial executor of the degenerative processes - [9] is substantiated by the fact that NFT load and spreading closely correlates with the severity and progression of the disease. Moreover, Tau pathology is associated with a growing list of neurodegenerative diseases referred to as "Tauopathies". And most importantly, exonic as well as intronic mutations in the Tau gene (MAPT) linked to these Tauopathies $[8,9]$, demonstrate that Tau is causally linked to neurodegenerative processes. Finally, accumulating evidence indicates that Tau-pathology can spread in a prion-like fashion to different brain regions: the spreading of misfolding of Tau to functionally connected brain regions [19-25], points towards a self-propagating "prion-like" effect - eventually following initiation of the cascade by $\mathrm{A} \beta$. These data position Tau as an important therapeutic target in Tauopathies but also in AD [9], and highlight the need to understand its exact pathological role. Most importantly, the outcome of these trials highlighted the need to understand the relation between $\mathrm{A} \beta$ and Tau and their respective contributions to the pathogenetic process.

\section{A $\beta$-induced Tau-pathology: experimental support for $A \beta$-induced Tau-pathology in cellular models, animal models and from patient biomarkers}

Despite the many criticisms against the amyloid cascade hypothesis, accumulating evidence obtained in in vitro and in vivo models and in patients provides solid experimental support for the hypothesis, and particularly for A $\beta$-induced Tau-pathology. More importantly these data position $A \beta$ as accelerator/initiator and Tau as executor of the pathogenetic process, designating their interaction as crucial triggering event in AD. In depth analysis of the mechanisms and the relation between different pathological characteristics and their role in the etiology, should allow the design of finetuned therapies for AD with increased efficacy. More particularly, the molecular or physical identity of the toxic form(s) of $A \beta$ (denoted $A \beta^{*}$ ), and of Tau (denoted Tau*), temporal and spatial localization of their action(s), (cell-autonomous or not, pre- or post-synaptic, intra- or extra-cellular), the respective contribution of amyloid and Tau to the etiology of $\mathrm{AD}$, and the mechanistic link(s) between amyloid and Tau pathology should be investigated for this purpose.

We here present an overview of in vitro and in vivo models available for further analysis of $A \beta$-induced Taupathology, which remains to be mechanistically resolved unequivocally. The existence of the apparent panoply of different models and their diversity is to be considered a particular asset to delineate those mechanisms that are robustly and consistently linked with $A \beta$-induced Taualterations.

\section{In vitro models of $A \beta$-induced Tau alterations}

In vitro experiments using various cell types, ranging from neuronal cell lines to primary hippocampal and cortical neurons and hippocampal organotypic cultures, have demonstrated $\mathrm{A} \beta$-induced Tau-alterations. These include increased phosphorylation and cytoplasmic and dendritic translocation, often linked to neurodegeneration which was Tau or even P-Tau dependent [26-38]. Most difficult to identify are the signaling cascades involved and/or the exact identity of $A \beta$ peptides involved. Definition of the exact form of $A \beta$-peptides is furthermore hampered by the fact that there is a continuous interconversion between different physical forms of the self-assembling $A \beta$ peptides. The variety of forms of amyloid peptides used experimentally, ranged from overexpression of mutant APP, to the extracellular application of oligomeric or fibrillar $A \beta_{(1-40 ; 1-42 ; 1-43,25-35)}$ in concentrations ranging widely. Most experiments were 
performed with synthetic $A \beta[26-30,32,33,35,37,38]$, but also with naturally secreted $A \beta$ or $A \beta$ dimers and oligomers extracted from human AD brains [36]. Application of amyloid peptides increased Tau-phosphorylation and altered Tau conformation to various extent, often associated with or dependent on GSK3 activation [26,28-31,35,38], which was reported to occur downstream of NMDA-receptor signaling [38]. Other signaling pathways have been reported including CAMKK2-AMPK kinase [37] and C-Jun N-terminal kinase [33], further hampering the identification of a common or primary mechanism(s). Finally, neurons differentiated from induced pluripotent stem cells (iPSC) from fibroblasts of 2 patients with familial AD with an APP gene duplication, demonstrated increased Tau phosphorylation at Thr-231, associated with GSK3 activation, while beta-secretase inhibition reduced p-Tau and GSK3 activation [39]. Besides GSK3, several other signaling mechanisms have been implicated in amyloid induced Tau-alterations in primary neurons or other neuronal cell lines, thereby not allowing a conclusive identification of the cascade(s) involved. Although identification and validation of the primary mechanism(s) in in vivo systems is required, compelling evidence - summarized above - indicates that $A \beta$ induces pathologically relevant Tau-alterations in neurons in vitro.

\section{In vivo models of $A \beta$-induced Tau-pathology}

A growing list of different animal AD models has reproducibly and robustly recapitulated $A \beta$-induced Taupathology. Although initial mouse models expressing mutant APP or mutant APP/PS1 without overexpression of Tau did not display neurofibrillary tangles nor robust Tau aggregation in mouse brain, subtle changes on endogenous mouse Tau induced by high $A \beta$ loads encompassed Tau hyperphosphorylation. Furthermore, models with high plaque loads consistently displayed presence of dystrophic neurites containing hyperphosphorylated, pathological Tau surrounding senile plaques [40-44]. The lack of formation of NFT could be ascribed to the low propensity of endogenous mouse Tau to form NFTs within the life span of mice without Tau overexpression. Transgenic rats overexpressing mutant APP/PS1 displayed increased Tau-alterations in the brains, primarily demonstrated with antibodies against $\mathrm{p}$-Tau and conformationally altered Tau, independent of overexpression of Tau, on the wild-type Tau genetic background $[45,46]$. The difference with mouse models might be due to different properties of murine and rat Tau, particularly the expression of different isoforms and/or possibly different levels of expression. Importantly, 3 seminal papers have demonstrated $A \beta$-induced formation of NFTs in mice overexpressing human mutant Tau [47-49]. Injection of synthetic pre-aggregated $A \beta$ peptides in the brains of Tau transgenic mice, resulted - albeit to a rather limited extent - in the induction of NFTs remote from the injection site, in neurons functionally connected with the site of injection [47]. These data point towards extracellular $A \beta$ as a contributor of amyloid induced Taupathology. Secondly, crossing mutant APP transgenic mice with TauP301S mice resulted in increased numbers of NFTs - in female offspring only - [48]. Finally, anti-A $\beta$ immunization in a model with combined amyloid and Tau-pathology reduced early pathological changes in Tau phosphorylation $[49,50]$. These findings were further confirmed and extended towards more robust induction of Tau-pathology in different combinations of Tau transgenic mice with transgenic mice overexpressing mutant APP or APP/PS1, and following injection of $A \beta$ peptide enriched brain extracts from mice or patients [51-56]. Furthermore, soluble $A \beta$ and $A \beta$-oligomers induced Tau-phosphorylation in the brains of wild-type Tau overexpressing mice [57]. More recently, APP/amyloid induced NFT formation was demonstrated in Tau transgenic mice expressing human wild type Tau (3R/4R) [58]. These different results are summarized in Additional file 1: Table $\mathrm{S} 1$ and indicate that $\mathrm{A} \beta$ induced Tau-pathology is very reproducible and consistently recapitulated in different models. In contrast, amyloid pathology was either not affected [53-55] or not aggravated by Tau-pathology [56]. The availability of the parental mouse strains thereby allows analysis of the respective contributions to the AD-related phenotypic features. We recently described a model with robust combined amyloid and Tau-pathology, which displayed a dramatic aggravation of Tauopathy compared to the single Tau transgenic mice (Figures 1 and 2). Comparative analysis with the parental amyloid and Tau only mice, demonstrated that aggravated Tau-pathology contributed to synaptic and cognitive deficits and to hippocampal atrophy in this model [55]. Moreover, dramatic hippocampal atrophy was demonstrated and obvious de visu during immunohistochemical analysis, thereby recapitulating an $\mathrm{AD}$ pathological feature not displayed in all models in a robust way. Taken together, animal models of $\mathrm{AD}$ have reproducibly and robustly recapitulated $\mathrm{A} \beta$-induced Tau-pathology in a variety of different in vivo models, while Tau-pathology did not induce increased amyloid pathology.

\section{AD patients: an integrated model of biomarker analysis and histopathological analysis: $A \beta$ accelerates antecedent subcortical Tau-pathology}

The most relevant data for AD research are undoubtedly patient data, encompassing combined analysis of clinical assessment, postmortem histopathological analysis, genetics and dynamic biomarker analysis. Yet these studies are confronted with more limited possibilities for mechanistic analysis. The obligatory histopathological 


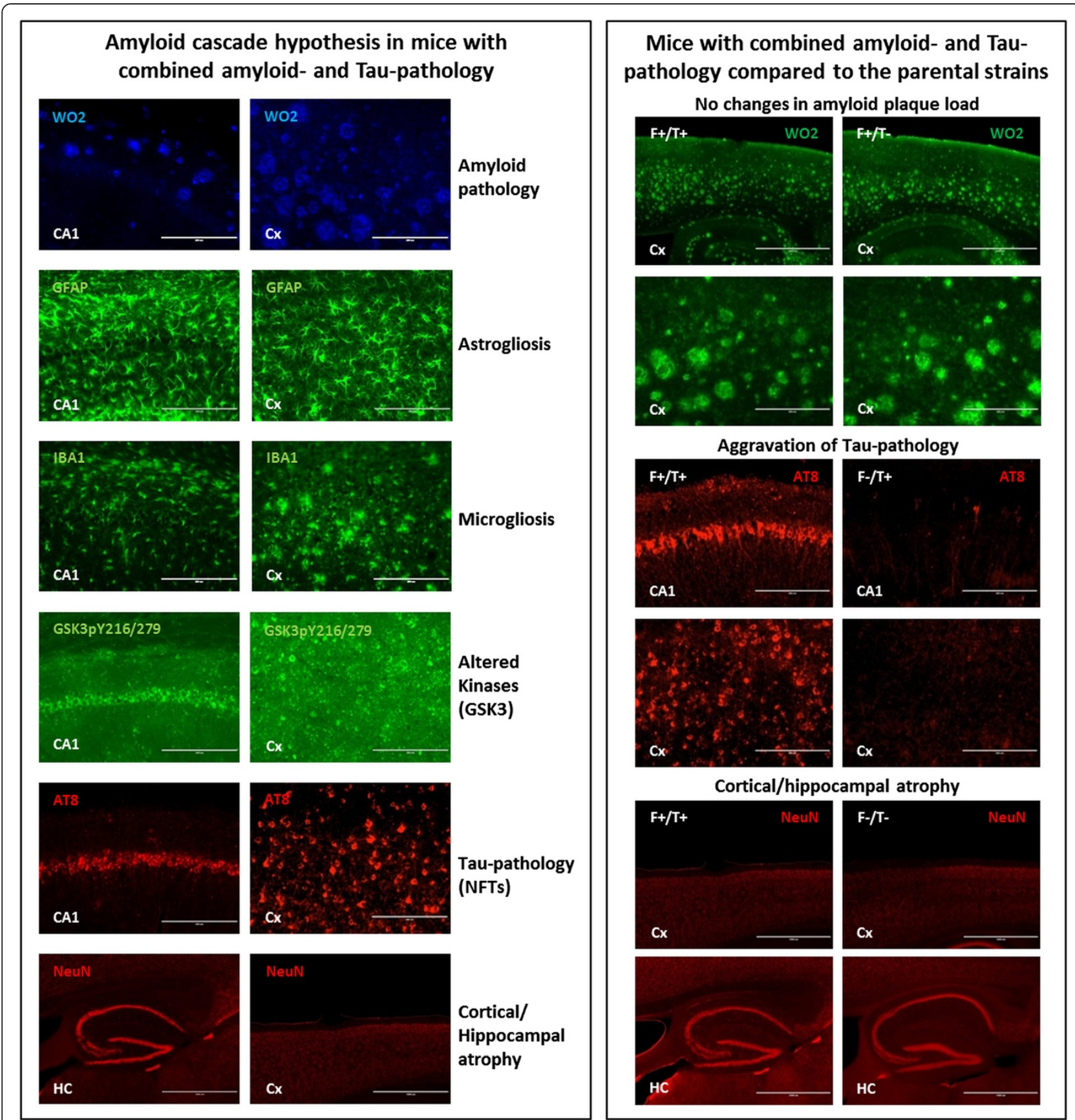

Figure 1 Amyloid cascade hypothesis in transgenic mice with combined amyloid and Tau pathology (left panel). Hippocampal (HC; CA1) and cortical (CX) immunohistochemical staining for amyloid plaques (anti-Aß, WO2), astrocytes (GFAP), microglia (Iba1), P-GSK3 (GSK3pT216/279), P-Tau (anti-pTau, AT-8) and NeuN for cortical/hippocampal atrophy (all images are 20X, except NeuN at 4X) is presented in transgenic mice expressing mutant APP/PS1 and mutant Tau [55]. These mice were generated by crossing mutant APP/PS1 and mutant Tau mice, respectively denoted as F+/T(5xFAD; [59]) and F-/T+(TauP301S; [60]). Of note, AT-8 staining was optimized to match Gallyas silver staining patterns, hence representing NFTs (data not shown). Main pathological features found in $\mathrm{F}+/ \mathrm{T}+$ mice (right panel). Immunolabeling with anti-A $(\mathrm{WO} 2)$, showing no changes in amyloid plaque load in the cortex of $\mathrm{F}+/ \mathrm{T}+$ and $\mathrm{F}+/ \mathrm{T}$ - mice (upper panel, $4 \mathrm{x}$ and $20 \mathrm{x}$ ); Aggravation of Tau-pathology, anti-pTau (AT-8) staining (NFT), in hippocampal CA1 region and cortex of $\mathrm{F}+/ \mathrm{T}+$ compared to $\mathrm{F}-/ \mathrm{T}+$ parental strain transgenic mice (middle panel, 20x); anti-neuronal nuclear staining (NeuN) showing decreased cortical and hippocampal area in $\mathrm{F}+/ \mathrm{T}+$ compared to $\mathrm{F}-\mathrm{T}$ - mice (lower panel, $4 \times$ ). 


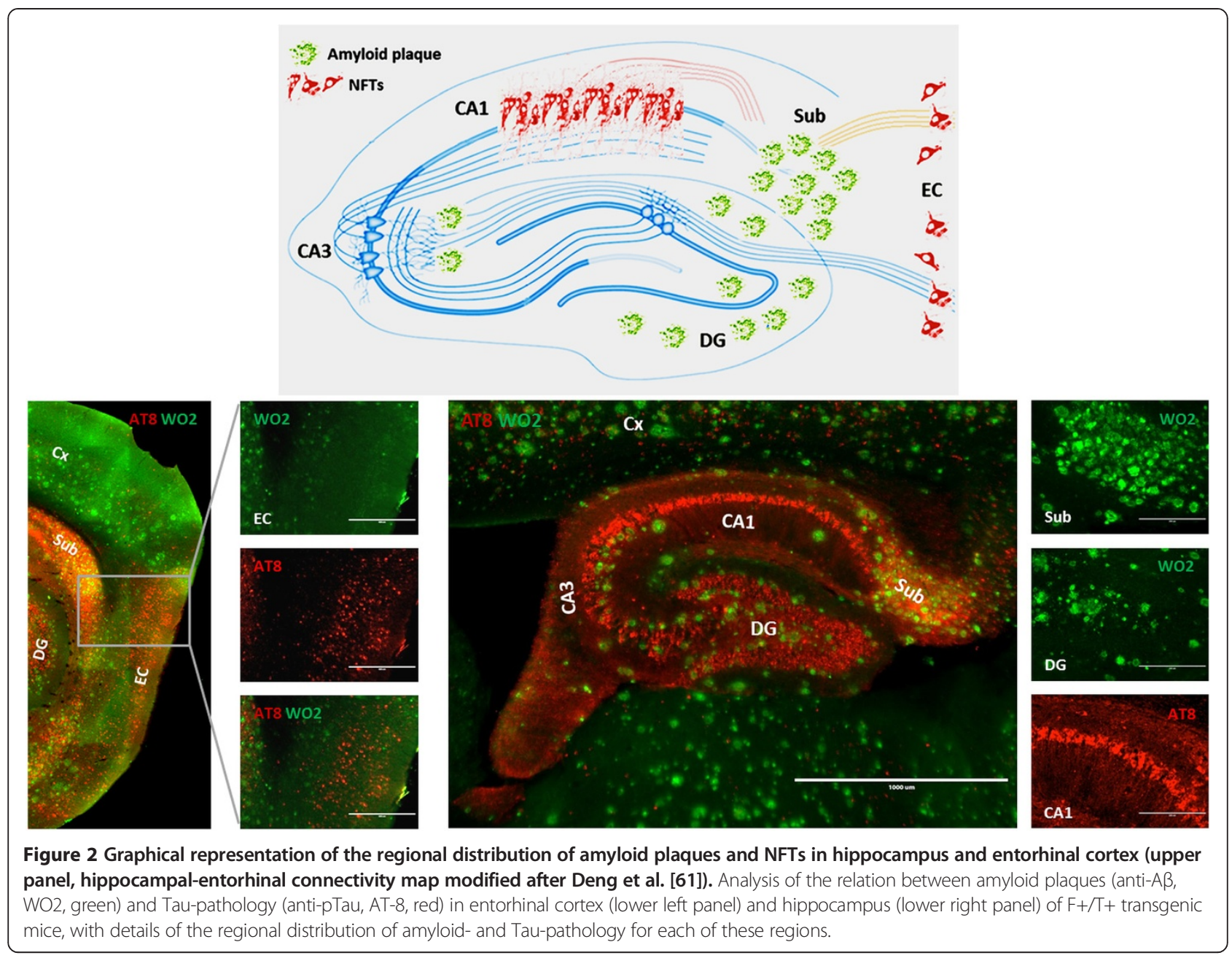

signature of $\mathrm{AD}$, is the co-occurrence of amyloid plaques and neurofibrillary tangles highlighting the importance of the two respective aggregated proteins $A \beta$ and Tau $[1,4,5]$. Their respective contributions, their chronological importance and interrelation have been a matter of intense animated debates since their discovery (from "Tauists/Baptist" to "chicken or egg"). As elegant discussions and in depth reviews of patient data are provided by others, we restrict the discussion here to a concise description of the integrated hypothesis which reconciles these discussions [1,62-72]. Dynamic biomarker analysis as indicators of key pathological features in $\mathrm{AD}$, has elegantly addressed the temporal evolution of these processes in relation to each other and to disease progression [65,71]. Measures of cerebrospinal fluid (CSF) A 342 and PET amyloid imaging were used as indicators of brain $A \beta$ deposition. Increased levels of CSF total Tau ( $\mathrm{t}$-Tau) and phosphorylated Tau (p-Tau) were taken as indicators of NFT burden in these studies [65,71]. Hypometabolism on fluorodeoxyglucose (FDG) PET and atrophy on structural MRI as measures of neurodegeneration. Dynamic biomarker analysis revealed a prototypical sequence of biomarker changes in the pathogenic process $[65,71]$. Earliest changes appeared in CSF A $\beta 42$, closely followed by amyloid PET imaging with an important lag period before the first symptoms. Alterations in CSF Tau (t-Tau and p-Tau) appear later in the disease process and precede cognitive decline and brain atrophy $[65,71]$. Although this sequence is completely in line with the amyloid cascade hypothesis as stated above [1], it was confronted with seemingly contradictory histopathological data demonstrating appearance of Tau-pathology early in life in asymptomatic individuals. Braak et al. demonstrated that Tau-pathology occurs first in limbic regions (entorhinal cortex and CA1) and even earlier in locus coeruleus in brain stem in very young cognitively normal individuals in the absence of amyloid pathology [66]. Progression of Tau-pathology occurs in a stereotypic way, which has been accepted as standard for staging the disease process $[5,73,74]$. This pattern is characterized by first appearance of NFTs in transentorhinal cortex (Stages I-II), subsequent appearance in hippocampal CA1 
(II-IV), and subsequent spreading to temporal (V) and isocortical areas (VI) [5,73,74]. Although these data demonstrate that Tau-pathology can occur prior to amyloid pathology, neuropathological evaluation by Price and Morris further elaborated these findings. They demonstrated that early Tau-pathology associated with normal ageing, was markedly increased and progressed more rapidly in individuals with $A \beta$ pathology $[62,64,67,71]$. A $\beta$ pathophysiological changes were thereby proposed "to qualitatively transform and accelerate the antecedent subcortical Tauopathy leading to neocortical spread of NFTs" [62-64,67,71].

We would like to integrate in this discussion compelling data from in vitro and in vivo models. Although we take into account the limitations of animal models, often using multiple mutations, overexpression (even of multiple genes sometimes), the invariable demonstration of A $\beta$-induced Tau-alterations in all these different models [45-57] very strongly support its relevance in the pathogenetic process. Conversely, the fact that in these models Tau-pathology did not affect or aggravate amyloid pathology argues rather against $\mathrm{A} \beta$ downstream of Tau as recently proposed [69]. Intriguingly, $\mathrm{A} \beta$ accumulation in $\mathrm{AD}$ patients occurs temporally and anatomically distinct from Tauopathy and is able to accelerate Tau pathology and to facilitate neurodegeneration $[63,67,71,73,75]$. This is strikingly in line with data obtained in animal models $[47,51,52,55]$, demonstrating occurrence of $A \beta$-induced Tau-pathology along neuronal projections. This includes our model(s), in which NFTs invariably develop early and robust in CA1 region of hippocampus, which is nearly devoid of amyloid plaques but projects to brain regions with high and early plaque load [52,55] (Figure 2). Similar data, underscoring A $\beta$-induced Tau-pathology along neuronal connections, were obtained in different models following injection of $\mathrm{A} \beta$ [47], or $\mathrm{A} \beta$-containing brain extracts [51] or different $\mathrm{APP} / \mathrm{Tau}$ mice [52]. In addition, besides a robust aggravation of Tau-pathology also hippocampal atrophy was significantly increased in mice with combined amyloid and Tau-pathology (APP/PS1/Tau mice) compared to the parental strain, with Tau-pathology only [55]. The latter is in line with the fact that in patients amyloid pathology not only accelerates Tau-pathology, but also facilitates associated neurodegeneration [67].

Taken together, data from in vitro and in vivo models and from patient analysis support a model in which $A \beta$ accumulation acts as a triggering event in the pathogenetic process by accelerating antecedent - relatively silent - Tau-pathology. Hence understanding this triggering event of A $\beta$-induced Tau-pathology is absolutely critical to understand $\mathrm{AD}$ and for development of therapeutic strategies, requiring analysis in in vitro and in vivo models.

\section{In vivo models with $A \beta$-induced Tau-pathology: tools to explore pathways linking amyloid and Tau-pathology}

Although mechanisms linking amyloid and Tau-pathology have not been conclusively and exhaustively identified, available data support several potential mechanisms that can contribute exclusively or concomitantly. We here use a reductionist approach and limit the discussion to mechanisms which are corroborated or are consistent with experimental data in our models [52,55] (Figure 3), thereby not excluding contributions of mechanisms not presented here. Theoretically, $A \beta$ peptides may interact directly or indirectly with neurons to induce Tau-alterations. First, direct interactions with neurons that have been reported include specific binding to several neuronal receptors (cfr 4.1) or, because of the sticky nature of amyloid peptides, less specific interaction with membranes and proteins. Secondly, indirect mechanisms may contribute to amyloid induced Tau-pathology, including amyloid induced inflammation via glial cells (cfr 4.2). Finally, in view of the recently observed cross-seeding between misfolded protein species, we need to consider that amyloid peptides may act as direct seeds for Tau-aggregation (cfr 4.3). This latter option has not yet been experimentally explored in detail, although some data are consistent with the hypothesis that pre-aggregated misfolded $A \beta$ peptides could seed and propagate Tau-misfolding and hence aggregation by cross-seeding.

\section{Direct mechanisms of amyloid induced Tau-alterations - interaction with neuronal receptors and membranes}

From the initial definition of amyloid plaques as extracellular $A \beta$ aggregates and NFTs as intraneuronal Tau aggregates, an interaction of extracellular $A \beta$ with neurons through membranes or receptors is proposed to be required for $\mathrm{A} \beta$-induced Tau-pathology. This view, however, was complicated by the identification of intraneuronal forms of $A \beta$, extracellular forms of Tau and different forms of $A \beta$ peptides as toxic candidate(s). Nevertheless, as injection of amyloid peptides - synthetic or APP mouse brain derived - induce Tau-pathology in Tau transgenic mice $[47,51]$, extracellularly applied A $\beta$ contributes to Tau alterations hence most straightforward requires interaction with neuronal receptors and/ or membranes. Many studies have demonstrated interactions between receptors and $A \beta$ peptides. Binding of $A \beta$ to different types of receptors has been reported, including alpha7 nicotinic acetylcholine receptors $(\alpha 7$ nAChR), NMDA and AMPA receptors - directly or indirectly -, the Ephrin-type B2 receptor (EphB2), insulin receptors, the receptor for advanced glycation endproducts (RAGE), the prion protein receptor (PrP-receptor), the mouse paired immunoglobulin-like receptor (PirB) and its human counterpart, leukocyte immunoglobulin-like 

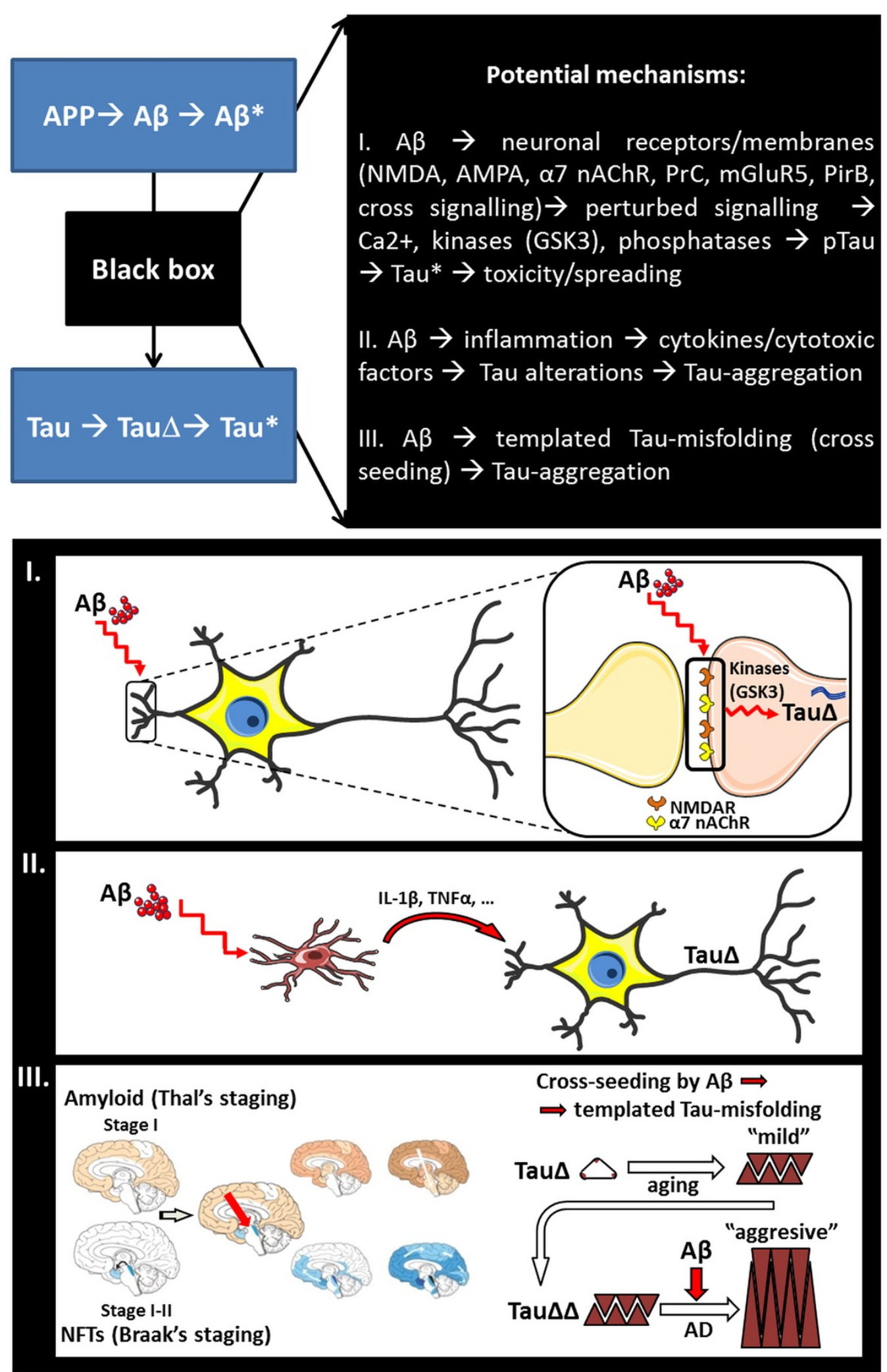

Figure 3 Schematic presentation of proposed mechanisms involved in A $\beta$-induced Tau-aggregation as discussed in this review (elements in panel I. and II. modified from Servier Medical Art; elements in panel III. modified from Jucker and Walker [76], Thal et al. [75], Braak and Braak [73]). 
receptor (LilrB2) [77-90]. In addition, to specific binding of amyloid peptides to receptors, more non-specific binding of the "sticky" amyloid peptides to membranes or membrane-proteins must be considered as a mechanism of action of amyloid toxicity [77].

Monomeric or oligomeric forms of $\mathrm{A} \beta_{1-42}$ have been demonstrated to bind with high affinity to $\alpha 7$ nicotinic acetylcholine receptors [78], which was inhibited by $\alpha 7$ $\mathrm{nAChR}$ ligands and found to be involved in amyloid induced synaptic and cognitive defects [78,91]. Depending on the form of the $A \beta$ peptide that binds the receptor, the physiological response varies [78]. In vitro findings using neuroblastoma and ex vivo synaptosomes demonstrated increased Tau-phosphorylation (Ser-202, Thr181, and Thr-231) following $A \beta$ peptide binding to $\alpha 7$ nAChR, which thereby represents a receptor potentially involved in amyloid induced Tau-pathology. Involvement of $\alpha 7 \mathrm{nAChR}$ in $\mathrm{A} \beta$-induced Tau-aggregation in animal models remains to be further explored in detail.

Mechanisms involved in A $\beta$-induced synaptic dysfunction are under meticulous analysis (excellently reviewed in [92-96]). Accumulating evidence supports a role of NMDA-receptors in the etiology of $A D$, by $A \beta$ mediated effects on synaptic dysfunction and their - indirect interaction with $A \beta$ peptides [95]. Effects of $A \beta$ on synaptic plasticity resulting in shifting synaptic potentiation (LTP) to synaptic depression (LTD), have been consistently reported in different APP transgenic mice and in different experiments using extracellular application of different forms of - oligomeric - A $\beta$ to hippocampal slices [92-96]. Several studies have indicated downstream effects of amyloid peptides on NMDA-receptor function $[95,97,98]$. A $\beta$ derived diffusible ligands (ADDLs) have been demonstrated to bind to synaptic sites in primary neuronal cultures, co-localizing with but not completely overlapping with NMDA receptors $[97,98]$. Hence, A $\beta$ peptides were proposed to indirectly interact with NMDA-receptors, potentially through the EphB2 receptor, a tyrosine kinase receptor known to regulate NMDA receptors or other receptors [88]. Different reports further demonstrated that prolonged $A \beta$ incubation promotes endocytosis of synaptic NMDA receptors - particularly the NR2B subtype -, resulting in depression of NMDA evoked currents and reduced CREB signaling required for long term memory [95,97-99]. Several mechanisms have been invoked to explain impaired NMDA-function and an "LTP to LTD shift" following $A \beta$ incubation. These included a role for extrasynaptic NR2B receptors, conformational changes of the NMDA receptors, a switch in NMDAR composition from GluN2B to GluN2A [99], changes in downstream signaling cascades or indirectly via mGluR5 [100]. Several studies further indicated a modulatory role of Tau in A $\beta$-induced excitotoxicity [101] linked to NMDA- receptors. Initially, excitotoxicity, seizures and premature death in APP transgenic mice have been demonstrated to be rescued by Tau-deficiency [102-104]. Follow-up studies further revealed that Tau-dependent targeting of fyn couples the NMDA-receptor to excitoxicity and that mistargetting of fyn mitigates $A \beta$ toxicity [94,101,105-108]. Recent evidence indicates a role for the $A \beta$-fyn-Tau triad in impaired LTP and cognition [104]. Other toxic effects of Tau and $A \beta$ may be related to this excitotoxity, for instance $A \beta$-induced defects in axonal transport [109] or mitochondrial dysfunction [110], but may also arise through other yet to be defined mechanisms. Taken together, compelling data support a role of NMDA-receptors in A $\beta$-induced impaired synaptic plasticity - shifting synaptic potentiation (LTP) to synaptic depression (LTD) pathways.

Of note is the demonstration of a role of GSK3 $\beta$ as regulatory switch between LTD and LTP [111] and the fact that $A \beta$-induced deficits in LTP are rescued by GSK3 $\beta$ inhibition [112]. Finally, A $\beta$-induced reduction of NMDA-dependent LTP was linked to increased Tauphosphorylation and GSK3 activation in hippocampal slices [104]. These data could point to a role of NMDAreceptors in $A \beta$-induced changes in Tau, possibly via GSK3 $\beta$. This hypothesis is consistent with - yet not proven by - findings of increased GSK3 activation in 2 different models of $A \beta$-induced Tau-pathology that we have analyzed [52,55], and with the fact that inhibition of GSK3 using adeno-associated-viral-mediated knockdown in a model with combined amyloid and Taupathology could reduce the latter [113]. Detailed analysis of a potential link between $A \beta$-induced effects on NMDAR-dependent synaptic dysfunction - or different A $\beta$-induced synaptic defects - and the amyloid induced pathological alterations in Tau leading to Tau-aggregation needs to be further performed and its consistency and robustness needs to be proven in different models.

Although a complete review of $A \beta$-receptor or $A \beta$ membrane interactions is beyond the scope of this work, we here would like to emphasize that unequivocal and consistent identification of the receptor(s) or neuronal membrane interaction and the downstream signaling cascades primarily responsible for amyloid induced Taupathology is still lacking. With regard to $A \beta$-receptors some puzzling questions remain, as previously raised $[89,96]$ i) Which are the common characteristics of an $\mathrm{A} \beta$ receptor? Is there a common structure or sequence that allows its binding? ii) Which are the specific (oligomeric) forms of $A \beta$ that bind to the receptors? iii) Which is the toxic form of $A \beta$ ? - Does this form bind to a specific receptor? - and particularly in the context of this review: iv) Does binding of amyloid peptide to this receptor mediate amyloid induced Tau-pathology? and if so v) Via which signaling cascades? 
In case of involvement of a neuronal receptor in $A \beta$ induced Tau-aggregation, the complete pathway between binding of $A \beta$ to this receptor(s) and induced Taualterations and Tau-aggregation remains to be identified in detail. Comparative analysis in different models of amyloid induced Tau-pathology to pinpoint this mechanism in an unequivocal way is required and enabled by the availability of different models.

\section{Amyloid induced inflammation - an inducer of pathological Tau-alterations}

Senile plaques are marked by the presence of astro- and microgliosis closely associated with amyloid plaque deposition [3-5]. In addition, astro- and microgliosis are invariably detected in brains of $\mathrm{AD}$ patients, originally already described by A. Alzheimer, although not directly used as a diagnostic hallmark for $\mathrm{AD}$ [3-5]. In vitro data support a role for micro- and astroglial roles in $A \beta-$ induced Tau-phosphorylation [114-116] as co-cultures with glial cells increased $A \beta$-induced Tau-phosphorylation in primary neurons [114-116]. Furthermore, in vivo models have invariably and consistently recapitulated astro- and microgliosis induced by amyloid pathology $[44,115]$. And, different reports have demonstrated that Tau-pathology is dramatically aggravated by acute and chronic inflammatory insults that induce micro- or astrogliosis [117-119]. It follows that $A \beta$-induced inflammation can contribute to $A \beta$-induced Tau pathology. Consistent with this result is the fact that blocking of IL-1 signaling, using an IL-1-R antibody attenuated Tau-pathology in triple transgenic mice [118], while increasing IL-1 $\beta$ exacerbated Tau-pathology [120]. An exhaustive review of the role of inflammation in AD models is beyond the scope of this work, but it will be important to corroborate these findings in different models and particularly to identify the role - and molecular mechanisms - of inflammation in A $\beta$-induced Tau-pathology.

\section{Amyloid peptides may act as seeds to qualitatively transform and accelerate antecedent Tau-pathology by "cross-seeding" mechanisms: Transformation of "mild Tau-strains" to "aggressive Tau-strains" by A $\beta$, triggering accelerated prion-like spreading of Tau-pathology along neuronal circuits - "a working hypothesis"}

Recent data have indicated self-propagation of pathogenic protein aggregates in a remarkable variety of neurodegenerative disorders ranging from AD, to Parkinson's disease, Huntington's disease to Tauopathies [20,76,121]. Specific proteins are misfolded and can subsequently act as seeds that structurally induce misfolding of proteins, causing them to aggregate in pathogenic assemblies ranging from small oligomers to large fibrillar amyloids. In this way, formation of minute amounts of misfolded proteins can act as self-propagating agents which initiate and propagate protein misfolding to functionally connected brain areas $[20,76,121]$. These prion-like spreading properties have recently been demonstrated for Tau [19-22], and could contribute to the characteristic spreading of Tau aggregates, resulting in their spatio- and temporal characteristic spreading to brain regions, as documented by Braak and Braak [73]. Aggregated misfolded Tau extracted from brains of transgenic mice and of different patients suffering from different Tauopathies resulted in seeding and propagation of Tau-pathology in a seed dependent manner in brains of wild type Tau transgenic mice $[19,20,22]$. Similar findings have been reported for misfolded alphasynuclein in neurons in culture and in mouse brain [122-125]. Intriguingly, misfolded alpha-synuclein seeds were able to initiate and propagate Tau-aggregation, revealing the potential of cross-seeding between different types of misfolded proteins [126]. Several reports have indicated that $A \beta$ peptides also display prion-like seeding $[76,121]$, enabling initiation and propagation of amyloid plaque formation to remote brain regions. Previous studies demonstrated that $A \beta$ and Tau in vitro can form soluble complexes [127]. Interestingly, in different models, injection of pre-aggregated synthetic amyloid peptides [47], or aggregated amyloid peptide enriched brain extracts [51] induced Tau-aggregation at the injection site but also in functionally connected brain regions remote from the injection site. This indicates that aggregated amyloid peptides can initiate and propagate Tauaggregation in functionally connected brain regions $[47,51]$. In line with these findings, we observed in our model, as described above, a consistent and robust induction of NFT formation (e.g. CA1) in regions with only very scarce plaques, but functionally connected to brain regions with high plaque density (subiculum) [55] (Figure 2). In view of these data, a cross-seeding mechanism of misfolded pre-aggregated $A \beta$ peptides to seed Tau-aggregation should be considered and further experimentally addressed as a potential mechanism of A $\beta$-induced Tau-pathology. Interestingly, such a mechanism would reconcile histopathological and biomarker data in patients, demonstrating that antecedent Taupathology is qualitatively transformed and accelerated by amyloid pathology in anatomically distinct brain regions. Tauopathy thereby becomes qualitatively transformed by cross-seeding by $A \beta$, accelerating its subsequent spreading along functional brain circuitries. This could be in line with a change of Tau-conformation or "Taustrain" [25] from a milder (associated with normal ageing) into a more aggressively propagating "Tau-strain" (associated with AD) by cross-seeding or templating by $A \beta$. The pre-existence of Tau-pathology may thereby be a requirement, underscoring why $A \beta$ pathology specifically affects neurons with pre-existing Tau-pathology (Braak stage I-II), and not nearby neurons. Although 
this is an appealing hypothesis it needs to be experimentally addressed in detail.

\section{In vivo models with $A \beta$-induced Tau-pathology to gain in depth understanding of $A \beta$-induced Tau-pathology: pathological entities of $A \beta$ and Tau and (cellular) localization}

Equally or even more enigmatic than the pathways linking amyloid and Tau remains the identification of the exact molecular and physical (oligomer $A \beta^{2,3, \ldots x}$, fibrils) nature of the toxic forms of amyloid entities involved, as well as whether the mechanism of action is cellautonomous or non-cell autonomous, intra-neuronal or extracellular, synaptic or extra-synaptic, acting through neuronal connections, or by immediate vicinity. The existence of multiple and different models represents an extra asset to address these questions and confirm a potential mechanism as an important contributor in different models. Models with combined amyloid and Tau pathology and synergism are available and are required to elucidate the mechanisms of $A \beta$-induced Tau-pathology, through intervention studies, and comparison with the amyloid and Tau pathology only models for deconvolution.

\section{Conclusion}

We here presented accumulating evidence in in vitro models, in vivo models and from biomarkers in patients that supports the amyloid cascade hypothesis, particularly $A \beta$-induced acceleration of Tau-pathology as a critical trigger in AD. Furthermore, we presented diverse models that recapitulate $\mathrm{A} \beta$-induced Tau-pathology and reviewed some potential contributing mechanisms. This mechanism may be linked to downstream effects of $A \beta$-induced synaptic defects, or to indirect effects mediated by amyloid induced inflammation. It thereby likely involves interactions of $A \beta$ species with (neuronal) receptors, non-receptor proteins and/or membranes, that need to be identified. Furthermore, cross-seeding of misfolded proteins, in which $A \beta$ cross-seeding of Tau, induces transition from mild Tau-strains to more aggressive Tau-strains and thereby triggers prion-like spreading of Tauopathy along neuronal circuitries, was suggested as a potential mechanism. This was based on the distinct spatio-temporal distribution of amyloid and Taupathology, which was also observed in transgenic $\mathrm{AD}$ models. A unifying mechanism of amyloid induced Tau-pathology still needs to be identified, which reconciles different previous data-sets, and which can be consistently and unequivocally demonstrated in different models with amyloid induced Tau-pathology. Most importantly, in depth understanding of $A \beta$-induced Tau-pathology in terms of identification of the exact molecular entity, exact molecular mechanism, and their respective contributions to and interrelation with associated pathological features (synaptic dysfunction, neurodegeneration, brain atrophy, inflammation) is absolutely required to define fine-tuned therapeutic strategies with a higher success in preventing or halting AD.

\section{Additional file}

Additional file 1: Table S1. A $\beta$ induced Tau pathology in in vivo models*

\section{Competing interests}

The authors declare that they have no competing interests. D. Terwel is involved in Contract Research at reMYND.

\section{Authors' contributions}

All the authors (ICS, BV, DT, ID) contributed to the writing of the manuscript. All authors read and approved the final manuscript.

\section{Acknowledgments}

We thank the Belgian Fonds National pour la Recherche Scientifique -Fonds de la Recherche Scientifique (FNRS-FRS; Qualified Researcher, Impulse

Financing, Research (redits), the Institute for the Promotion of Innovation by Science and Technology (IWT) (Belgium), the European Commission

(AgedBrainSYSBIO, FP7, ECGA No305299) and the Interuniversity Attraction Poles Programme-Belgian State-Belgian Science Policy, The Belgian Fonds de la Recherche Scientifique Médicale, for financial support. We thank F. Van Leuven for his contribution to this review.

\section{Addendum}

After acceptance of this review, a model of A $\beta$-induced Tau pathology in a culture dish, using a 3 dimensional neuronal culture was published by Choi and colleagues [128]. This model recapitulates the formation of amyloid plaques and A $\beta$-induced Tau-pathology. This article and the subsequent discussion further emphasizes the importance of understanding the process of $A \beta$-induced Tau-pathology. In our review we provide an overview of available models to study this process and propose some working hypotheses. The published neuronal culture model is an important addition.

\section{Author details}

${ }^{1}$ Catholic University of Louvain, Institute of Neuroscience, Alzheimer Dementia, Av. E. Mounier 53, Av. Hippocrate 54, B-1200 Brussels, Belgium. ${ }^{2}$ reMYND nv, Gaston Geenslaan 1, B-3001 Leuven, Belgium.

Received: 12 May 2014 Accepted: 14 October 2014

Published: 18 November 2014

\section{References}

1. Hardy J, Selkoe DJ: The amyloid hypothesis of Alzheimer's disease: progress and problems on the road to therapeutics. Science 2002, 297(5580):353-356.

2. Spires-Jones TL, Stoothoff WH, de CA, Jones PB, Hyman BT: Tau pathophysiology in neurodegeneration: a tangled issue. Trends Neurosci 2009, 32(3):150-159.

3. Perrin RJ, Fagan AM, Holtzman DM: Multimodal techniques for diagnosis and prognosis of Alzheimer's disease. Nature 2009, 461(7266):916-922.

4. Selkoe DJ: Alzheimer's disease. Cold Spring Harb Perspect Biol 2011, 3(7):a004457. 1-16.

5. Serrano-Pozo A, Frosch MP, Masliah E, Hyman BT: Neuropathological alterations in Alzheimer disease. Cold Spring Harb Perspect Med 2011, 1(1):a006189.

6. Tanzi RE, Bertram L: Twenty years of the Alzheimer's disease amyloid hypothesis: a genetic perspective. Cell 2005, 120(4):545-555.

7. Tanzi RE: The genetics of Alzheimer disease. Cold Spring Harb Perspect Med 2012, 2(10):a006296. 1-10

8. Hutton M, Lendon CL, Rizzu P, Baker M, Froelich S, Houlden H, PickeringBrown S, Chakraverty S, Isaacs A, Grover A, Hackett J, Adamson J, Lincoln S, Dickson D, Davies P, Petersen RC, Stevens M, de Graaff E, Wauters E, van 
Baren J, Hillebrand M, Joosse M, Kwon JM, Nowotny P, Che LK, Norton J, Morris JC, Reed LA, Trojanowski J, Basun H, et al: Association of missense and 5 '-splice-site mutations in tau with the inherited dementia FTDP-17. Nature 1998, 393(6686):702-705.

9. Brunden KR, Trojanowski JQ, Lee VM: Advances in tau-focused drug discovery for Alzheimer's disease and related tauopathies. Nat Rev Drug Discov 2009, 8(10):783-793.

10. Postina R, Schroeder A, Dewachter I, Bohl J, Schmitt U, Kojro E, Prinzen C, Endres K, Hiemke C, Blessing M, Flamez P, Dequenne A, Godaux E, van Leuven F, Fahrenholz F: A disintegrin-metalloproteinase prevents amyloid plaque formation and hippocampal defects in an Alzheimer disease mouse model. J Clin Invest 2004, 113(10):1456-1464.

11. Vassar R, Bennett BD, Babu-Khan S, Kahn S, Mendiaz EA, Denis P, Teplow DB, Ross S, Amarante P, Loeloff R, Luo Y, Fisher S, Fuller J, Edenson S, Lile J, Jarosinski MA, Biere AL, Curran E, Burgess T, Louis JC, Collins F, Treanor J, Rogers G, Citron M: Beta-secretase cleavage of Alzheimer's amyloid precursor protein by the transmembrane aspartic protease BACE. Science 1999, 286(5440):735-741.

12. De SB, Saftig P, Craessaerts K, Vanderstichele H, Guhde G, Annaert W, Von FK, van LF: Deficiency of presenilin-1 inhibits the normal cleavage of amyloid precursor protein. Nature 1998, 391(6665):387-390.

13. De SB, Iwatsubo T, Wolfe MS: Presenilins and gamma-secretase: structure, function, and role in Alzheimer disease. Cold Spring Harb Perspect Med 2012, 2(1):a006304

14. Dewachter I, Van LF: Secretases as targets for the treatment of Alzheimer's disease: the prospects. Lancet Neurol 2002, 1(7):409-416.

15. Schenk D, Barbour R, Dunn W, Gordon G, Grajeda H, Guido T, Hu K, Huang J, Johnson-Wood K, Khan K, Kholodenko D, Lee M, Liao Z, Lieberburg I, Motter R, Mutter L, Soriano F, Shopp G, Vasquez N, Vandevert C, Walker S, Wogulis M, Yednock T, Games D, Seubert P: Immunization with amyloidbeta attenuates Alzheimer-disease-like pathology in the PDAPP mouse. Nature 1999, 400(6740):173-177.

16. Schenk D, Basi GS, Pangalos MN: Treatment strategies targeting amyloid beta-protein. Cold Spring Harb Perspect Med 2012, 2(9):a006387.

17. St George-Hyslop PH, Morris JC: Will anti-amyloid therapies work for Alzheimer's disease? Lancet 2008, 372(9634):180-182.

18. Small SA, Duff K: Linking Abeta and tau in late-onset Alzheimer's disease: a dual pathway hypothesis. Neuron 2008, 60(4):534-542.

19. Clavaguera F, Bolmont T, Crowther RA, Abramowski D, Frank S, Probst A, Fraser G, Stalder AK, Beibel M, Staufenbiel M, Jucker M, Goedert M, Tolnay $\mathrm{M}$ : Transmission and spreading of tauopathy in transgenic mouse brain. Nat Cell Biol 2009, 11(7):909-913.

20. Goedert M, Clavaguera F, Tolnay M: The propagation of prion-like protein inclusions in neurodegenerative diseases. Trends Neurosci 2010, 33(7):317-325.

21. Iba M, Guo JL, McBride JD, Zhang B, Trojanowski JQ, Lee VM: Synthetic tau fibrils mediate transmission of neurofibrillary tangles in a transgenic mouse model of Alzheimer's-like tauopathy. J Neurosci 2013, 33(3):1024-1037

22. Clavaguera F, Akatsu H, Fraser G, Crowther RA, Frank S, Hench J, Probst A, Winkler DT, Reichwald J, Staufenbiel M, Ghetti B, Goedert M, Tolnay M: Brain homogenates from human tauopathies induce tau inclusions in mouse brain. Proc Natl Acad Sci U S A 2013, 110(23):9535-9540.

23. Yanamandra K, Kfoury N, Jiang H, Mahan TE, Ma S, Maloney SE, Wozniak DF, Diamond MI, Holtzman DM: Anti-tau antibodies that block tau aggregate seeding in vitro markedly decrease pathology and improve cognition in vivo. Neuron 2013, 80(2):402-414

24. Guo JL, Lee VM: Cell-to-cell transmission of pathogenic proteins in neurodegenerative diseases. Nat Med 2014, 20(2):130-138.

25. Sanders DW, Kaufman SK, DeVos SL, Sharma AM, Mirbaha H, Li A, Barker SJ, Foley AC, Thorpe JR, Serpell LC, Miller TM, Grinberg LT, Seeley WW, Diamond Ml: Distinct tau prion strains propagate in cells and mice and define different tauopathies. Neuron 2014, 82(6):1271-1288.

26. Takashima A, Noguchi K, Sato K, Hoshino T, Imahori K: Tau protein kinase I is essential for amyloid beta-protein-induced neurotoxicity. Proc Natl Acad Sci U S A 1993, 90(16):7789-7793.

27. Busciglio J, Lorenzo A, Yeh J, Yankner BA: beta-amyloid fibrils induce tau phosphorylation and loss of microtubule binding. Neuron 1995, 14(4):879-888.

28. Ferreira A, Lu Q, Orecchio L, Kosik KS: Selective phosphorylation of adult tau isoforms in mature hippocampal neurons exposed to fibrillar A beta. Mol Cell Neurosci 1997, 9(3):220-234.
29. Takashima A, Honda T, Yasutake K, Michel G, Murayama O, Murayama M, Ishiguro K, Yamaguchi H: Activation of tau protein kinase I/glycogen synthase kinase-3beta by amyloid beta peptide (25-35) enhances phosphorylation of tau in hippocampal neurons. Neurosci Res 1998, 31(4):317-323.

30. Zheng WH, Bastianetto S, Mennicken F, Ma W, Kar S: Amyloid beta peptide induces tau phosphorylation and loss of cholinergic neurons in rat primary septal cultures. Neuroscience 2002, 115(1):201-211.

31. Ma QL, Lim GP, Harris-White ME, Yang F, Ambegaokar SS, Ubeda OJ, Glabe CG, Teter B, Frautschy SA, Cole GM: Antibodies against beta-amyloid reduce Abeta oligomers, glycogen synthase kinase-3beta activation and tau phosphorylation in vivo and in vitro. J Neurosci Res 2006, 83(3):374-384

32. De Felice FG, Wu D, Lambert MP, Fernandez SJ, Velasco PT, Lacor PN, Bigio EH, Jerecic J, Acton PJ, Shughrue PJ, Chen-Dodson E, Kinney GG, Klein WL: Alzheimer's disease-type neuronal tau hyperphosphorylation induced by A beta oligomers. Neurobiol Aging 2008, 29(9):1334-1347.

33. Ma QL, Yang F, Rosario ER, Ubeda OJ, Beech W, Gant DJ, Chen PP, Hudspeth B, Chen C, Zhao Y, Vinters HV, Frautschy SA, Cole GM: Betaamyloid oligomers induce phosphorylation of tau and inactivation of insulin receptor substrate via c-Jun $\mathrm{N}$-terminal kinase signaling: suppression by omega-3 fatty acids and curcumin. J Neurosci 2009, 29(28):9078-9089.

34. Zempel $H$, Thies E, Mandelkow E, Mandelkow EM: Abeta oligomers cause localized $\mathrm{Ca}(2+)$ elevation, missorting of endogenous Tau into dendrites, Tau phosphorylation, and destruction of microtubules and spines. J Neurosci 2010, 30(36):11938-11950.

35. Zeng KW, Ko H, Yang HO, Wang XM: Icariin attenuates beta-amyloidinduced neurotoxicity by inhibition of tau protein hyperphosphorylation in PC12 cells. Neuropharmacology 2010, 59(6):542-550.

36. Jin M, Shepardson N, Yang T, Chen G, Walsh D, Selkoe DJ: Soluble amyloid beta-protein dimers isolated from Alzheimer cortex directly induce Tau hyperphosphorylation and neuritic degeneration. Proc Natl Acad Sci U S A 2011, 108(14):5819-5824

37. Mairet-Coello G, Courchet J, Pieraut S, Courchet V, Maximov A, Polleux F: The CAMKK2-AMPK kinase pathway mediates the synaptotoxic effects of Abeta oligomers through Tau phosphorylation. Neuron 2013, 78(1):94-108.

38. Tackenberg C, Grinschgl S, Trutzel A, Santuccione AC, Frey MC, Konietzko U, Grimm J, Brandt R, Nitsch RM: NMDA receptor subunit composition determines beta-amyloid-induced neurodegeneration and synaptic loss. Cell Death Dis 2013, 4:e608.

39. Israel MA, Yuan SH, Bardy C, Reyna SM, Mu Y, Herrera C, Hefferan MP, Van GS, Nazor KL, Boscolo FS, Carson CT, Laurent LC, Marsala M, Gage FH, Remes AM, Koo EH, Goldstein LS: Probing sporadic and familial Alzheimer's disease using induced pluripotent stem cells. Nature 2012, 482(7384):216-220.

40. Games D, Adams D, Alessandrini R, Barbour R, Berthelette P, Blackwell C, Carr T, Clemens J, Donaldson T, Gillespie F: Alzheimer-type neuropathology in transgenic mice overexpressing V717F beta-amyloid precursor protein. Nature 1995, 373(6514):523-527.

41. Sturchler-Pierrat C, Abramowski D, Duke M, Wiederhold KH, Mistl C, Rothacher S, Ledermann B, Burki K, Frey P, Paganetti PA, Waridel C, Calhoun ME, Jucker M, Probst A, Staufenbiel M, Sommer B: Two amyloid precursor protein transgenic mouse models with Alzheimer disease-like pathology. Proc Natl Acad Sci U S A 1997, 94(24):13287-13292.

42. Holcomb L, Gordon MN, McGowan E, Yu X, Benkovic S, Jantzen P, Wright K, Saad I, Mueller R, Morgan D, Sanders S, Zehr C, O'Campo K, Hardy J, Prada CM, Eckman C, Younkin S, Hsiao K, Duff K: Accelerated Alzheimer-type phenotype in transgenic mice carrying both mutant amyloid precursor protein and presenilin 1 transgenes. Nat Med 1998, 4(1):97-100.

43. Moechars D, Dewachter I, Lorent K, Reverse D, Baekelandt V, Naidu A, Tesseur I, Spittaels K, Haute CV, Checler F, Godaux E, Cordell B, Van Leuven F: Early phenotypic changes in transgenic mice that overexpress different mutants of amyloid precursor protein in brain. J Biol Chem 1999, 274(10):6483-6492.

44. Duyckaerts C, Potier MC, Delatour B: Alzheimer disease models and human neuropathology: similarities and differences. Acta Neuropathol 2008, 115(1):5-38.

45. Echeverria V, Ducatenzeiler A, Dowd E, Jänne J, Grant SM, Szyf M, Wandosell F, Avila J, Grimm H, Dunnett SB, Hartmann T, Alhonen L, Cuello AC: Altered mitogen-activated protein kinase signaling, tau hyperphosphorylation 
and mild spatial learning dysfunction in transgenic rats expressing the $\beta$-amyloid peptide intracellularly in hippocampal and cortical neurons. Neuroscience 2004, 129(3):583-592.

46. Cohen RM, Rezai-Zadeh K, Weitz TM, Rentsendorj A, Gate D, Spivak I, Bholat $Y$, Vasilevko V, Glabe CG, Breunig JJ, Rakic P, Davtyan H, Agadjanyan MG, Kepe V, Barrio JR, Bannykh S, Szekely CA, Pechnick RN, Town T: A transgenic Alzheimer rat with plaques, tau pathology, behavioral impairment, oligomeric abeta, and frank neuronal loss. J Neurosci 2013, 33(15):6245-6256.

47. Gotz J, Chen F, Van DJ, Nitsch RM: Formation of neurofibrillary tangles in P301I tau transgenic mice induced by Abeta 42 fibrils. Science 2001 293(5534):1491-1495.

48. Lewis J, Dickson DW, Lin WL, Chisholm L, Corral A, Jones G, Yen SH, Sahara N, Skipper L, Yager D, Eckman C, Hardy J, Hutton M, McGowan E: Enhanced neurofibrillary degeneration in transgenic mice expressing mutant tau and APP. Science 2001, 293(5534):1487-1491.

49. Oddo S, Billings L, Kesslak JP, Cribbs DH, LaFerla FM: Abeta immunotherapy leads to clearance of early, but not late, hyperphosphorylated tau aggregates via the proteasome. Neuron 2004, 43(3):321-332.

50. Oddo S, Caccamo A, Kitazawa M, Tseng BP, LaFerla FM: Amyloid deposition precedes tangle formation in a triple transgenic model of Alzheimer's disease. Neurobiol Aging 2003, 24(8):1063-1070.

51. Bolmont T, Clavaguera F, Meyer-Luehmann M, Herzig MC, Radde R, Staufenbiel M, Lewis J, Hutton M, Tolnay M, Jucker M: Induction of tau pathology by intracerebral infusion of amyloid-beta -containing brain extract and by amyloid-beta deposition in APP $\mathrm{x}$ Tau transgenic mice. Am J Pathol 2007, 171(6):2012-2020.

52. Terwel D, Muyllaert D, Dewachter I, Borghgraef $P$, Croes S, Devijver $H$, Van LF: Amyloid activates GSK-3beta to aggravate neuronal tauopathy in bigenic mice. Am J Pathol 2008, 172(3):786-798.

53. Hurtado DE, Molina-Porcel L, Iba M, Aboagye AK, Paul SM, Trojanowski JQ, Lee VM: A\{beta\} accelerates the spatiotemporal progression of tau pathology and augments tau amyloidosis in an Alzheimer mouse model. Am J Pathol 2010, 177(4):1977-1988.

54. Saul A, Sprenger F, Bayer TA, Wirths O: Accelerated tau pathology with synaptic and neuronal loss in a novel triple transgenic mouse model of Alzheimer's disease. Neurobiol Aging 2013, 34(11):2564-2573.

55. Stancu IC, Ris L, Vasconcelos B, Marinangeli C, Goeminne L, Laporte V, Haylani LE, Couturier J, Schakman O, Gailly P, Pierrot N, Kienlen-Campard P, Octave JN, Dewachter I: Tauopathy contributes to synaptic and cognitive deficits in a murine model for Alzheimer's disease. FASEB J 2014 28(6):2620-2631.

56. Heraud C, Goufak D, Ando K, Leroy K, Suain V, Yilmaz Z, De DR, Authelet M, Laporte V, Octave JN, Brion JP: Increased misfolding and truncation of tau in APP/PS1/tau transgenic mice compared to mutant tau mice. Neurobiol Dis 2014, 62:100-112.

57. Chabrier MA, Blurton-Jones M, Agazaryan AA, Nerhus JL, Martinez-Coria H, LaFerla FM: Soluble abeta promotes wild-type tau pathology in vivo. J Neurosci 2012, 32(48):17345-17350.

58. Umeda T, Maekawa S, Kimura T, Takashima A, Tomiyama T, Mori H: Neurofibrillary tangle formation by introducing wild-type human tau into APP transgenic mice. Acta Neuropathol 2014, 127(5):685-698.

59. Oakley H, Cole SL, Logan S, Maus E, Shao P, Craft J, Guillozet-Bongaarts A, Ohno M, Disterhoft J, Van Eldik L, Berry R, Vassar R: Intraneuronal $\beta$-amyloid aggregates, neurodegeneration, and neuron loss in transgenic mice with five familial Alzheimer's disease mutations: potential factors in amyloid plaque formation. J Neurosci 2006, 26(40):10129-10140.

60. Yoshiyama Y, Higuchi M, Zhang B, Huang SM, Iwata N, Saido TC, Maeda J, Suhara T, Trojanowski JQ, Lee VM: Synapse loss and microglial activation precede tangles in a P301S tauopathy mouse model. Neuron 2007, 53(3):337-351.

61. Deng W, Aimone JB, Gage FH: New neurons and new memories: how does adult hippocampal neurogenesis affect learning and memory? Nat Rev Neurosci 2010, 11(5):339-350.

62. Price $J$, Morris JC: Tangles and plaques in nondemented aging and "preclinical" Alzheimer's disease. Ann Neurol 1999, 45(3):358-368.

63. Delacourte A, Sergeant N, Champain D, Wattez A, Maurage CA, Lebert F, Pasquier F, David JP: Nonoverlapping but synergetic tau and APP pathologies in sporadic Alzheimer's disease. Neurology 2002, 59(3):398-407.

64. Price JL, Morris JC: So what if tangles precede plaques? Neurobiol Aging 2004, 25(6):721-723.
65. Jack CR Jr, Knopman DS, Jagust WJ, Shaw LM, Aisen PS, Weiner MW, Petersen RC, Trojanowski JQ: Hypothetical model of dynamic biomarkers of the Alzheimer's pathological cascade. Lancet Neurol 2010, 9(1):119-128.

66. Braak H, Del TK: The pathological process underlying Alzheimer's disease in individuals under thirty. Acta Neuropathol 2011, 121(2):171-181.

67. Musiek ES, Holtzman DM: Origins of Alzheimer's disease: reconciling cerebrospinal fluid biomarker and neuropathology data regarding the temporal sequence of amyloid-beta and tau involvement. Curr Opin Neurol 2012, 25(6):715-720.

68. Attems J, Jellinger KA: Amyloid and tau: neither chicken nor egg but two partners in crime! Acta Neuropathol 2013, 126(4):619-621.

69. Braak H, Del TK: Amyloid-beta may be released from non-junctional varicosities of axons generated from abnormal tau-containing brainstem nuclei in sporadic Alzheimer's disease: a hypothesis. Acta Neuropathol 2013, 126(2):303-306.

70. Braak H, Del TK: Reply: the early pathological process in sporadic Alzheimer's disease. Acta Neuropathol 2013, 126(4):615-618.

71. Jack CR Jr, Knopman DS, Jagust WJ, Petersen RC, Weiner MW, Aisen PS, Shaw LM, Vemuri P, Wiste HJ, Weigand SD, Lesnick TG, Pankratz VS, Donohue MC, Trojanowski JQ: Tracking pathophysiological processes in Alzheimer's disease: an updated hypothetical model of dynamic biomarkers. Lancet Neurol 2013, 12(2):207-216.

72. Mann DM, Hardy J: Amyloid or tau: the chicken or the egg? Acta Neuropathol 2013, 126(4):609-613.

73. Braak H, Braak E: Neuropathological stageing of Alzheimer-related changes. Acta Neuropathol 1991, 82(4):239-259.

74. Hyman BT, Trojanowski JQ: Consensus recommendations for the postmortem diagnosis of Alzheimer disease from the National Institute on Aging and the Reagan Institute Working Group on diagnostic criteria for the neuropathological assessment of Alzheimer disease. J Neuropathol Exp Neurol 1997, 56(10):1095-1097.

75. Thal DR, Rub U, Orantes M, Braak H: Phases of A beta-deposition in the human brain and its relevance for the development of AD. Neurology 2002, 58(12):1791-1800.

76. Jucker M, Walker LC: Self-propagation of pathogenic protein aggregates in neurodegenerative diseases. Nature 2013, 501(7465):45-51.

77. Hertel C, Terzi E, Hauser N, Jakob-Rotne R, Seelig J, Kemp JA: Inhibition of the electrostatic interaction between beta-amyloid peptide and membranes prevents beta-amyloid-induced toxicity. Proc Natl Acad Sci U S A 1997, 94(17):9412-9416.

78. Wang HY, Lee DH, D'Andrea MR, Peterson PA, Shank RP, Reitz AB: betaAmyloid(1-42) binds to alpha7 nicotinic acetylcholine receptor with high affinity. Implications for Alzheimer's disease pathology. J Biol Chem 2000, 275(8):5626-5632.

79. Yan SD, Roher A, Chaney M, Zlokovic B, Schmidt AM, Stern D: Cellular cofactors potentiating induction of stress and cytotoxicity by amyloid beta-peptide. Biochim Biophys Acta 2000, 1502(1):145-157.

80. Lacor PN, Buniel MC, Chang L, Fernandez SJ, Gong Y, Viola KL, Lambert MP Velasco PT, Bigio EH, Finch CE, Krafft GA, Klein WL: Synaptic targeting by Alzheimer's-related amyloid beta oligomers. J Neurosci 2004, 24(45):10191-10200.

81. Verdier $Y$, Zarandi M, Penke B: Amyloid beta-peptide interactions with neuronal and glial cell plasma membrane: binding sites and implications for Alzheimer's disease. J Pept Sci 2004, 10(5):229-248.

82. Lacor PN, Buniel MC, Furlow PW, Clemente AS, Velasco PT, Wood M, Viola $\mathrm{KL}$, Klein WL: Abeta oligomer-induced aberrations in synapse composition, shape, and density provide a molecular basis for loss of connectivity in Alzheimer's disease. J Neurosci 2007, 27(4):796-807.

83. Simakova O, Arispe NJ: The cell-selective neurotoxicity of the Alzheimer's Abeta peptide is determined by surface phosphatidylserine and cytosolic ATP levels. Membrane binding is required for Abeta toxicity. J Neurosci 2007, 27(50):13719-13729.

84. Koffie RM, Meyer-Luehmann M, Hashimoto T, Adams KW, Mielke ML, GarciaAlloza M, Micheva KD, Smith SJ, Kim ML, Lee VM, Hyman BT, Spires-Jones TL: Oligomeric amyloid beta associates with postsynaptic densities and correlates with excitatory synapse loss near senile plaques. Proc Natl Acad Sci U S A 2009, 106(10):4012-4017.

85. Lauren J, Gimbel DA, Nygaard HB, Gilbert JW, Strittmatter SM: Cellular prion protein mediates impairment of synaptic plasticity by amyloid-beta oligomers. Nature 2009, 457(7233):1128-1132. 
86. Balducci C, Beeg M, Stravalaci M, Bastone A, Sclip A, Biasini E, Tapella L, Colombo L, Manzoni C, Borsello T, Chiesa R, Gobbi M, Salmona M, Forloni G: Synthetic amyloid-beta oligomers impair long-term memory independently of cellular prion protein. Proc Natl Acad Sci U S A 2010, 107(5):2295-2300

87. Gimbel DA, Nygaard HB, Coffey EE, Gunther EC, Lauren J, Gimbel ZA, Strittmatter SM: Memory impairment in transgenic Alzheimer mice requires cellular prion protein. J Neurosci 2010, 30(18):6367-6374.

88. Cisse M, Halabisky B, Harris J, Devidze N, Dubal DB, Sun B, Orr A, Lotz G, Kim DH, Hamto P, Ho K, Yu GQ, Mucke L: Reversing EphB2 depletion rescues cognitive functions in Alzheimer model. Nature 2011, 469(7328):47-52.

89. Benilova I, De SB: Neuroscience. Promiscuous Alzheimer's amyloid: yet another partner. Science 2013, 341(6152):1354-1355.

90. Kim T, Vidal GS, Djurisic M, William CM, Birnbaum ME, Garcia KC, Hyman BT, Shatz CJ: Human LilrB2 is a beta-amyloid receptor and its murine homolog PirB regulates synaptic plasticity in an Alzheimer's model. Science 2013, 341(6152):1399-1404.

91. Dziewczapolski G, Glogowski CM, Masliah E, Heinemann SF: Deletion of the alpha 7 nicotinic acetylcholine receptor gene improves cognitive deficits and synaptic pathology in a mouse model of Alzheimer's disease. J Neurosci 2009, 29(27):8805-8815.

92. Selkoe DJ: Alzheimer's disease is a synaptic failure. Science 2002, 298(5594):789-791.

93. Palop JJ, Mucke L: Synaptic depression and aberrant excitatory network activity in Alzheimer's disease: two faces of the same coin? Neuromolecular Med 2010, 12(1):48-55.

94. Ittner LM, Gotz J: Amyloid-beta and tau-a toxic pas de deux in Alzheimer's disease. Nat Rev Neurosci 2011, 12(2):65-72.

95. Malinow R: New developments on the role of NMDA receptors in Alzheimer's disease. Curr Opin Neurobiol 2012, 22(3):559-563.

96. Mucke L, Selkoe DJ: Neurotoxicity of amyloid beta-protein: synaptic and network dysfunction. Cold Spring Harb Perspect Med 2012, 2(7):a006338.

97. Snyder EM, Nong Y, Almeida CG, Paul S, Moran T, Choi EY, Nairn AC, Salter MW, Lombroso PJ, Gouras GK, Greengard P: Regulation of NMDA receptor trafficking by amyloid-beta. Nat Neurosci 2005, 8(8):1051-1058.

98. Dewachter I, Filipkowski RK, Priller C, Ris L, Neyton J, Croes S, Terwel D, Gysemans M, Devijver H, Borghgraef P, Godaux E, Kaczmarek L, Herms J, Van Leuven F: Deregulation of NMDA-receptor function and downstream signaling in APP[V717I] transgenic mice. Neurobiol Aging 2009, 30(2):241-256

99. Kessels HW, Nabavi S, Malinow R: Metabotropic NMDA receptor function is required for beta-amyloid-induced synaptic depression. Proc Natl Acad Sci U S A 2013, 110(10):4033-4038.

100. Hu NW, Nicoll AJ, Zhang D, Mably AJ, O'Malley T, Purro SA, Terry C, Collinge J, Walsh DM, Rowan MJ: mGlu5 receptors and cellular prion protein mediate amyloid-beta-facilitated synaptic long-term depression in vivo. Nat Commun 2014, 5:3374

101. Morris M, Maeda S, Vossel K, Mucke L: The many faces of tau. Neuron 2011, 70(3):410-426

102. Roberson ED, Scearce-Levie K, Palop JJ, Yan F, Cheng IH, Wu T, Gerstein H, Yu GQ, Mucke L: Reducing endogenous tau ameliorates amyloid betainduced deficits in an Alzheimer's disease mouse model. Science 2007, 316(5825):750-754

103. Roberson ED, Halabisky B, Yoo JW, Yao J, Chin J, Yan F, Wu T, Hamto P, Devidze N, Yu GQ, Palop JJ, Noebels JL, Mucke L: Amyloid-beta/Fyninduced synaptic, network, and cognitive impairments depend on tau levels in multiple mouse models of Alzheimer's disease. J Neurosci 2011, 31(2):700-711.

104. Shipton OA, Leitz JR, Dworzak J, Acton CE, Tunbridge EM, Denk F, Dawson HN, Vitek MP, Wade-Martins R, Paulsen O, Vargas-Caballero M: Tau protein is required for amyloid \{beta\}-induced impairment of hippocampal longterm potentiation. J Neurosci 2011, 31(5):1688-1692.

105. Haass C, Mandelkow E: Fyn-tau-amyloid: a toxic triad. Cell 2010, 142(3):356-358

106. Ittner LM, Ke YD, Delerue F, Bi M, Gladbach A, Van EJ, Wolfing H, Chieng BC, Christie MJ, Napier IA, Eckert A, Staufenbiel M, Hardeman E, Götz J: Dendritic function of tau mediates amyloid-beta toxicity in Alzheimer's disease mouse models. Cell 2010, 142(3):387-397.

107. Garg S, Timm T, Mandelkow EM, Mandelkow E, Wang Y: Cleavage of Tau by calpain in Alzheimer's disease: the quest for the toxic $17 \mathrm{kD}$ fragment. Neurobiol Aging 2011, 32(1):1-14.
108. Sydow A, Van der Jeugd A, Zheng F, Ahmed T, Balschun D, Petrova O, Drexler D, Zhou L, Rune G, Mandelkow E, D'Hooge R, Alzheimer C, Mandelkow EM: Tau-induced defects in synaptic plasticity, learning, and memory are reversible in transgenic mice after switching off the toxic Tau mutant. J Neurosci 2011, 31(7):2511-2525.

109. Vossel KA, Zhang K, Brodbeck J, Daub AC, Sharma P, Finkbeiner S, Cui B, Mucke $L$ : Tau reduction prevents $A \beta$-induced defects in axonal transport. Science 2010, 330(6001):198.

110. Rhein V, Song X, Wiesner A, Ittner LM, Baysang G, Meier F, Ozmen L, Bluethmann H, Dröse S, Brandt U, Savaskan E, Czech C, Götz J, Eckert A: Amyloid- $\beta$ and tau synergistically impair the oxidative phosphorylation system in triple transgenic Alzheimer's disease mice. Proc Natl Acad Sci 2009, 106(47):20057-20062.

111. Peineau S, Taghibiglou C, Bradley C, Wong TP, Liu L, Lu J, Lo E, Wu D, Saule $E$, Bouschet T, Matthews $P$, Isaac JT, Bortolotto ZA, Wang YT, Collingridge GL: LTP inhibits LTD in the hippocampus via regulation of GSK3beta. Neuron 2007, 53(5):703-717.

112. Jo J, Whitcomb DJ, Olsen KM, Kerrigan TL, Lo SC, Bru-Mercier G, Dickinson B, Scullion S, Sheng M, Collingridge G, Cho K: Abeta(1-42) inhibition of LTP is mediated by a signaling pathway involving caspase-3, Akt1 and GSK3beta. Nat Neurosci 2011, 14(5):545-547.

113. Hurtado DE, Molina-Porcel L, Carroll JC, Macdonald C, Aboagye AK, Trojanowski JQ, Lee VM: Selectively silencing GSK-3 isoforms reduces plaques and tangles in mouse models of Alzheimer's disease. J Neurosci 2012, 32(21):7392-7402.

114. Li Y, Liu L, Barger SW, Griffin WS: Interleukin-1 mediates pathological effects of microglia on tau phosphorylation and on synaptophysin synthesis in cortical neurons through a p38-MAPK pathway. J Neurosci 2003, 23(5):1605-1611.

115. Saez ET, Pehar M, Vargas MR, Barbeito L, Maccioni RB: Production of nerve growth factor by beta-amyloid-stimulated astrocytes induces p75NTRdependent tau hyperphosphorylation in cultured hippocampal neurons. J Neurosci Res 2006, 84(5):1098-1106.

116. Garwood CJ, Pooler AM, Atherton J, Hanger DP, Noble W: Astrocytes are important mediators of Abeta-induced neurotoxicity and tau phosphorylation in primary culture. Cell Death Dis 2011, 2:e167.

117. Bhaskar K, Konerth M, Kokiko-Cochran ON, Cardona A, Ransohoff RM, Lamb BT: Regulation of tau pathology by the microglial fractalkine receptor. Neuron 2010, 68(1):19-31.

118. Kitazawa M, Cheng D, Tsukamoto MR, Koike MA, Wes PD, Vasilevko V, Cribbs $\mathrm{DH}$, LaFerla FM: Blocking IL-1 signaling rescues cognition, attenuates tau pathology, and restores neuronal beta-catenin pathway function in an Alzheimer's disease model. J Immunol 2011, 187(12):6539-6549.

119. Sy M, Kitazawa M, Medeiros R, Whitman L, Cheng D, Lane TE, LaFerla FM: Inflammation induced by infection potentiates tau pathological features in transgenic mice. Am J Pathol 2011, 178(6):2811-2822.

120. Ghosh S, Wu MD, Shaftel SS, Kyrkanides S, LaFerla FM, Olschowka JA O'Banion MK: Sustained interleukin-1beta overexpression exacerbates tau pathology despite reduced amyloid burden in an Alzheimer's mouse model. J Neurosci 2013, 33(11):5053-5064.

121. Soto C, Estrada L, Castilla J: Amyloids, prions and the inherent infectious nature of misfolded protein aggregates. Trends Biochem Sci 2006, 31(3):150-155

122. Luk KC, Song C, O'Brien P, Stieber A, Branch JR, Brunden KR, Trojanowski JQ, Lee VM: Exogenous alpha-synuclein fibrils seed the formation of Lewy body-like intracellular inclusions in cultured cells. Proc Natl Acad Sci U S A 2009, 106(47):20051-20056

123. Volpicelli-Daley LA, Luk KC, Patel TP, Tanik SA, Riddle DM, Stieber A, Meaney $D F$, Trojanowski JQ, Lee VM: Exogenous alpha-synuclein fibrils induce Lewy body pathology leading to synaptic dysfunction and neuron death. Neuron 2011, 72(1):57-71.

124. Luk KC, Kehm V, Carroll J, Zhang B, O'Brien P, Trojanowski JQ, Lee VM: Pathological alpha-synuclein transmission initiates Parkinson-like neurodegeneration in nontransgenic mice. Science 2012, 338(6109):949-953.

125. Luk KC, Kehm VM, Zhang B, O'Brien P, Trojanowski JQ, Lee VM: Intracerebral inoculation of pathological alpha-synuclein initiates a rapidly progressive neurodegenerative alpha-synucleinopathy in mice. J Exp Med 2012, 209(5):975-986.

126. Guo JL, Covell DJ, Daniels JP, Iba M, Stieber A, Zhang B, Riddle DM, Kwong LK $X u Y$, Trojanowski JQ, Lee VM: Distinct alpha-synuclein strains differentially promote tau inclusions in neurons. Cell 2013, 154(1):103-117. 
127. Guo JP, Arai T, Miklossy J, McGeer PL: Abeta and tau form soluble complexes that may promote self aggregation of both into the insoluble forms observed in Alzheimer's disease. Proc Natl Acad Sci U S A 2006, 103(6):1953-1958.

128. Choi SH, Kim YH, Hebisch M, Sliwinski C, Lee S, D'Avanzo C, Chen H, Hooli B, Asselin C, Muffat J, Klee JB, Zhang C, Wainger BJ, Peitz M, Kovacs DM, Woolf CJ, Wagner SL, Tanzi RE, Kim DY: A three-dimensional human neural cell culture model of Alzheimer's disease. Nature 2014. doi:10.1038/ nature 13800.

doi:10.1186/1750-1326-9-51

Cite this article as: Stancu et al:: Models of $\beta$-amyloid induced Taupathology: the long and "folded" road to understand the mechanism. Molecular Neurodegeneration 2014 9:51.

\section{Submit your next manuscript to BioMed Central and take full advantage of:}

- Convenient online submission

- Thorough peer review

- No space constraints or color figure charges

- Immediate publication on acceptance

- Inclusion in PubMed, CAS, Scopus and Google Scholar

- Research which is freely available for redistribution 